\title{
Research Paper \\ A Comparative Investigation of the Bispecific Antibody: Expression in Expi293F Cells and E.coli
}

\author{
Reza Moazzami ${ }^{1}$ (), Hasan Mirzahosaini ${ }^{1}$ (1), Fatemeh Naddafi² ${ }^{(0)},{ }^{*}$ Fatemeh Davami $^{1}$ (1)
}

1. Iran Medical Biotechnology Research Center, Pasteur Institute of Iran, Tehran, Iran.

2. Pharmaceutical Sciences Research Center, Shahid Beheshti University of Medical Sciences, Tehran, Iran.

\begin{tabular}{|c|c|}
\hline $\begin{array}{l}\text { Use your device to scan } \\
\text { and read the article online }\end{array}$ & ditation Moazzami R, Mirzahosaini H, Naddafi F, Davami F. [A Comparative Investigation of the Bispecific Antibody: Expres- \\
\hline 口itipin & $\begin{array}{l}\text { sion in Expi293F Cells and E.coli (Persian)]. Quarterly of "The Horizon of Medical Sciences". 2021; 27(3):400-417. https://doi. } \\
\text { org/10.32598/hms.27.3.3478.1 }\end{array}$ \\
\hline 口iflis & doi https://doi.org/10.32598/hms.27.3.3478.1 \\
\hline
\end{tabular}

\section{(i) (5)}

Received: 31 Mar 2021

Accepted: 15 Jun2021

Available Online: $01 \mathrm{Jul} 2021$

Key words:

Blinatomomb, Dualcharacter antibody, Acute lymphoblastic leukemia

\section{A B STRACT}

Aims Dual-Character antibodies can simultaneously target two surface markers. Blinatumomab is a C19/ CD3 antibody from the BiTE family (Bispecific T cell engager antibody) and was approved by the US Food and Drug Administration for clinical use. This antibody effectively targets malignant cells in patients with acute infoblastic leukemia. In the production of large quantities of such antibodies on an industrial scale, selecting the appropriate host remains a critical issue. Mammalian cells and strains of E.coli are the most common hosts for producing antibodies and antibody components on an industrial scale, respectively. Methods \& Materials In this study, a dual-specific antibody was used in the mammalian system of plasmid pcDNA3.1 (+) and for expression in the bacterial system of plasmid pET22b. The antibody produced in both systems was purified using nickel affinity resin under similar conditions. Next, SDS-PAGE and Western blot analysis was performed on both study samples. Finally, the binding properties of the antibody secreted from both systems were assessed by the ELISA test.

Findings The present study results suggested that antibodies produced by the mammalian expression system provided better binding properties than the expression system in bacteria.

Conclusion This study indicated that in the case of antibodies to two traits of the BiTE family, like Blinatombe, mammalian cells generate a more efficient and successful expression system; although the bacterium can produce much larger amounts of the antibody.

\section{Extended Abstract}

\section{Introduction}

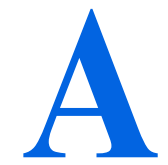

pplying monoclonal Antibodies (mAb) to diagnose and treat various diseases, including cancer, has become a standard and effective method. There exist $>70$ monoclonal antibodies on the world pharmaceutical market, and numerous are in various stages of testing [1]. However, in some cases, monoclonal antibodies have limi- tations, e.g., the size and complexity of the molecule reduce its potential to penetrate tumor tissues; the flat structure of the interacting segments complicates catalytic cavities to penetrate deep into enzymes $[2,3]$. To overcome such limitations and increase the antitumor activity of antibodies, there are various approaches, like antibody engineering to increase affinity; the invention of antibody conjugate antibodies or the use of antibody fragments; finally, the creation of bispecific antibodies. Binding to two different targets by a single antibody molecule is an intriguing idea in cancer treatment research. Such molecules can perform several

* Corresponding Author:

Fatemeh Davami

Address: Iran Medical Biotechnology Research Center, Pasteur Institute of Iran, Tehran, Iran.

Tel: +98 (912) 6046412

E-mail: f.davami@gmail.com 
functions, as follows: the inhibition of the cell surface receptor; simultaneous blockade of two ligands; the crosslinking of two surface receptors, and the placement of a $\mathrm{T}$ cell adjacent to the tumor [4]. Three dual-character antibodies have been licensed by legal authorities; catumaxomab [5], blinatumomab, and emicizumab [6]. The benefits of dual-character compounds include their bilateral effect on different tumor targets and their cumulative or synergistic drug effects due to the overlap of cancer signaling pathways. These antibodies come in a wide variety of formats, including those with and without Fc [4]. The BiTE Bispecific T cell engager format consists of two single antibody chains linked together by a polypeptide linker. In BiTEs, one arm is targeted against CD3 and one arm against the tumor antigen. The features of this format include the ability of Tcell-cell polyclonal antigen-dependent activation and the induction of T cell proliferation. Thus, BiTE has a great ability to lysis the target cell. Blinatumomab, or CD3 $\times$ CD19bsAb anti, is the first drug in the BiTE family to be introduced by Amgen in 2014 to treat Acute Lymphoblastic Leukemia (ALL) and Non-Hodgkin's Lymphoma (NHL) [7].

Blinatombe is a protein fusion with a molecular weight of $55 \mathrm{KD}$ that contains two scFv (Single Chain Fragment Variable) antibody chains. This protein consists of 4 variable domain cDNAs plus 3 linker peptides, 2 long linkers to bind to make the scFv fragment, and a short linker to bind the two fragments. This structure provides the flexibility and freedom of action required to connect each arm to the target epitopes located on the surface of the two cells. In the N-terminal part of this protein is scFv binding to murine CD19 antibody derived from mAb HD37. Moreover, in the $\mathrm{C}$-terminal part of the $\mathrm{scFv}$ is terminal binding to 3 $\mathrm{CD}$ antibody derived from $\mathrm{mAb}$ L2K murine antibody [8]. The presence of a hexahistidine sequence at the $\mathrm{C}$-terminus of this protein allows it to be purified by affinity resins Immobilized Metal Ion Affinity Chromatography (IMAC) [9].

The persistent and high expression of CD19 molecule on malignant $\mathrm{B}$ cells and its role in the survival and proliferation of these cells made it a target marker on B cells. Unlike CD20 and CD22, the CD19 receptor is expressed in almost all developmental stages of $\mathrm{B}$ cell lineage. It is a reliable marker for treating this category. Furthermore, in patients, almost $100 \%$ of malignant cells express this antigen [10]. CD19 is a PI3 kinase activator. This enzyme is a key element in signaling in malignant cells [11]. The in vitro performance of CD3 $\times$ CD19 anti in T cell and CD19 expression cells was strongly significant in simultaneous culture experiments. The minimum concentration required for lysis of CD19 target cells was approximately pg/mL [12].
Additionally, CD3+, CD4+, or CD8+ $\mathrm{T}$ cells present a similar ability to lysis target cells and perform so with vigor. Of course, naïve T cells are an exception [13]. Moreover, anti-CD3 $\times$ CD19 is sufficient for T cell activation and requires no prior activation or stimulants. $\mathrm{T}$ cell activation leads to the expression of CD69 and C25 as well as the upregulation of adhesion molecules, like CD2 on its surface. Besides, it releases inflammatory cytokines, such as IFNY, TNF $\alpha$, IL2, IL6, IL1, finally the sequential proliferation of T cells [14]. The mechanism of T cell-cell killing in CD19 target cells involves the formation of a strong cytolytic synapse between the two cells, followed by the depletion of the toxic proteins perforin and granzymes from the secretory $\mathrm{T}$ vesicles on the target cell. The activation of caspase enzymes in the target cell indicates the significance of the apoptosis pathway parallel to the pathway of secretory vesicles to destroy the target cell [8].

For producing therapeutic recombinant proteins, including monoclonal antibodies, various hosts are used, such as bacteria, baculovirus, yeast, plant cells, and mammalian cells [15]. Among these, the mammalian cell class due to its ability to produce protein by natural folding and creating proper post-translational modifications are especially important. Chinese Hamster Ovary (CHO) cell line is the most widely used cell line for generating antibodies; producing about two-thirds of recombinant therapeutic proteins in this class [16]. HEK293 human embryonic kidney is a human kidney embryonic cell. It is widely used for the transient expression of TGE recombinant proteins. Despite its epithelial origin, it adapts well to suspended culture conditions. Due to the human nature of this class, the recombinant proteins expressed in it are similar to human proteins concerning post-translational changes. Furthermore, the process of translation, folding, and maturation processes occur with considerable adequacy. The transient gene expression approach is commonly used to shortly produce large amounts of protein for the biochemical studies of the drug and to perform preclinical investigations [17, 18]. Expi 293 cell is a HEK293 cell-derived class for culture in high cell density suspension and serum-free culture medium. The chemically defined form of these properties makes this cell suitable for industrial production [19].

The mammalian cell expression system is currently the most common method of producing this antibody; however, Escherichia coli has the potential to produce proteins without a glycosylation pattern, as well as the ease of ordering the production process and the cost-effectiveness of the bacterial culture raw materials has made this host a suitable host for the production of Fc-free antibodies and dualspecific antibodies [20]. Accordingly, a significant portion of therapeutic proteins without glycosylation pattern is 
produced in this host, and BL21 (DE3) is among the most common industrial and research strains. The long history of industrial use of E. coli, as well as the appropriate rules of the drug production supervisory departments to this host, are significant advantages of this production platform [21].

Considering the single-chain and non-glycosylation of Blinatombe, the capacity of the bacterial expression system to produce this antibody was used; we compared it with the antibody produced in eukaryotic cells. This is because no such comparison has been made for the Blinatomb antibody. The great advantages of E. coli, as a suitable host include its industrial production parameters; the availability of inexpensive culture media for the production of biopharmaceuticals in this host; the expression of monoclonal antibodies of two BiTE family traits (due to no post-translational changes). The commercial manufacturer expressed Blinatomomb in the host of CHO. This study aimed to examine the expression and binding properties of antibodies expressed in both systems and compare them.

\section{Materials and Methods}

\section{Cells and consumables}

Expi293F cell and related culture medium (Expi293 recession Expression Medium) and its specific transfection agent (ExpiFectamine ${ }^{\mathrm{TM}} 293$ transfection Reagent), as well as Pen/Strep and L-Glu antibiotics and pcDNA3.1 (+) vector (Invitrogen; CA, USA), were prepared. Ni-NTA chromatographic resin was obtained from QIAGEN (USA). Trypan blue and 3-d3 aminobenzidine (DAB) and antihistamine conjugated with HRP and TMB were prepared from Sigma-Aldrich (USA). E.coli BL21 strain (DE3) and vector $\mathrm{pET}-22 \mathrm{~b}$ were obtained from Novagen (USA). Restriction enzymes were collected from Thermo Fisher Scientific (USA). NALM-6 and Jurkat cell lines were obtained from the cell bank of the Pasteur Institute of Iran.

\section{Expressive structures and expression in E.Coli}

The expression constructs expressing the two antibodies of blinatumomab from the PGH vector in the pET-22b vector were cloned by HindIII and NcoI enzymes. BL21 (DE3) strain was used for protein expression. The $\mathrm{pET}-22 \mathrm{~b}$ vector was designed for the periplasmic expression of the target protein. The strain transformed by the expressive vector in the LB medium was incubated to reach $\mathrm{OD}=0.5$ in a wavelength of $600 \mathrm{~nm}$. Then, $0.5 \mathrm{mM}$ IPTG was used for induction. The cells were isolated by centrifugation after 4 hours of culture. Besides, a culture batch without induction was considered as a negative control.
Expression structure and the expression of Expi293F cell line

The coding sequence of the blinatombe protein was cloned from the PGH vector into the pcDNA3.1 vector. This measure helped to construct the expression structure in the cellular system by two enzymes, NheI and HindIII. These expression constructs were then transfected into Expi293F cells. Expi293F cells were cultured in specific and without serum culture medium Expi293 тM expression medium with penicillin-streptomycin $(2 \mathrm{mM})$ antibiotics. The cells were cultured in a $\mathrm{CO}_{2}$ incubator shaker in a humid environment and in rotating glass bottles at 125 $\mathrm{rpm}$. The cells were passaged every three days at a density of approximately $3 \times 10^{5}$ cells $/ \mathrm{mL}$. The cell count method with trypanblo was employed to calculate the frequency of cells. In short, the transfection was performed according to the manufacturer's method, as follows: The day before the transfection, the cells were cultured in an additive-free medium. The next day, the transfectamine ${ }^{\text {TM }} 293$ reagents and plasmid were mixed with specific relativity. Incubations were added to the cells. After 16-18 hours, ExpiFectamine тм Transfection Enhancer 1 and 2 were added to the cells according to the manufacturer's instructions. On the seventh day, the supernatant was isolated from the cells and stored to assess expression.

\section{Protein purification}

To purify the antibodies expressed by the Expi293F cell line, Ni-NTA (Ni-Nitrilotriacetic acid) column was used. Initially, the cell soup was filtered by a $0.45 \mu \mathrm{m}$ filter. The column was then washed with a binding buffer $\left[\mathrm{NaH}_{2} \mathrm{PO}_{4}(50 \mathrm{mM}), \mathrm{NaCl}\right.$ $(300 \mathrm{mM})$, imidazole $(10 \mathrm{mM}), \mathrm{pH}=8.0)]$. Accordingly, $\mathrm{NaH}-$ ${ }_{2} \mathrm{PO}_{4}(50 \mathrm{mM}), \mathrm{NaCl}(300 \mathrm{mM})$, imidazole $(20 \mathrm{mM}), \mathrm{pH}=8.0$ were washed and finally buffered by $\mathrm{NaH}_{2} \mathrm{PO}_{4}(50 \mathrm{mM})$, $\mathrm{NaCl}(300 \mathrm{mM})$, imidazole $(250 \mathrm{mM} ; \mathrm{pH}=8.0)$. The purification of the protein expressed in bacteria was similar to that of the cell. The difference concerned the chemical composition of the triple buffers, i.e., changed as follows:

Binding buffer: $\left(100 \mathrm{mM} \mathrm{NaH}_{2} \mathrm{PO}_{4}, 10 \mathrm{mM}\right.$ Tris, $8 \mathrm{M}$ Urea $\mathrm{pH}=8$ );

Washing buffer: $\left(100 \mathrm{mM} \mathrm{NaH} \mathrm{PO}_{4}, 10 \mathrm{mM}\right.$ Tris, $8 \mathrm{M}$ Urea $\mathrm{pH}=6.3$ );

Elution buffer: (100mM NaH${ }_{2} \mathrm{PO}_{4}, 10 \mathrm{mM}$ Tris, $8 \mathrm{M}$ Urea $\mathrm{pH}=4.5$ ).

SDS PAGE and Western blot analysis 


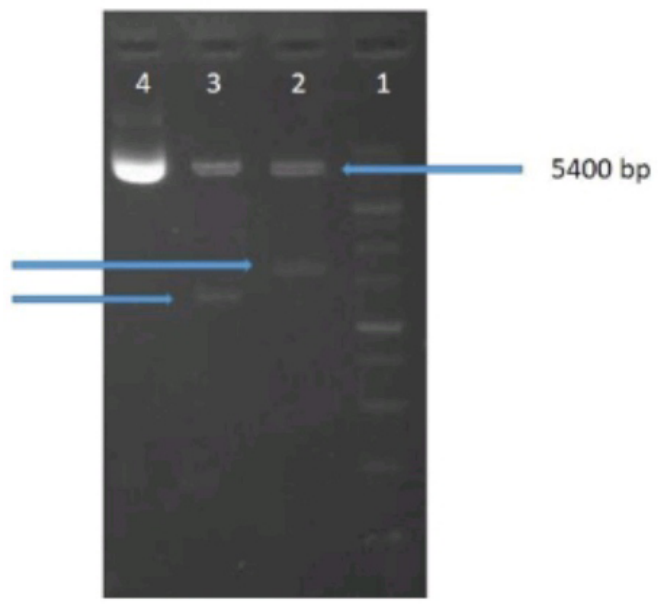

Figure 1. Gel electrophoresis of expression structures
B.

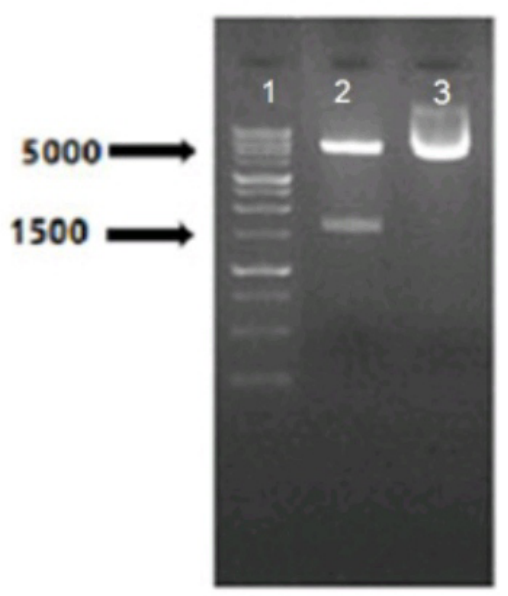

Quarterly of

The Horizon of Medical Sciences

A: Agarose gel electrophoresis related to antibody gene cloning in pcDNA3.1 vector for expression in Expi293F cell row 1) DNA marker $1 \mathrm{~kb}$ row 2) The digestion of gene construct containing antibody coding fragment [pcDNA3.1 + bsAb] by NheI restriction enzymes HindIII and the creation of fragments 5429 and 1587 bp of rows 3) The digestion of gene constructs containing antibody coding fragment [pcDNA3.1 + bsAb] by XhoI restriction enzymes Making fragments 5731 and 1269 bp of rows 4) Cloned gene structure [pcDNA3. $1+$ bsAb] not digested; B: Gel electrophoresis related to antibody gene cloning in vector pET-22b for expression in BL21 (DE3) strain 1) DNA marker 1kb. Row 2) Digestion of gene constructs containing antibody-coding fragments by NcoI and HindIII restriction enzymes and generation of 5493 and 1587 bp fragments Row 3) Undigested gene constructs.

SDS PAGE and Western blot analysis were implemented to evaluate protein expression. Kumasi blue staining was used to detect proteins. The proteins were electrophoresed in a $12 \%$ gel at 100 volts for 80 minutes. SDS PAGE was followed by Western blotting. This process was performed by a semi-dry transfer cell Trans-Blot (Biorad) using nitro-

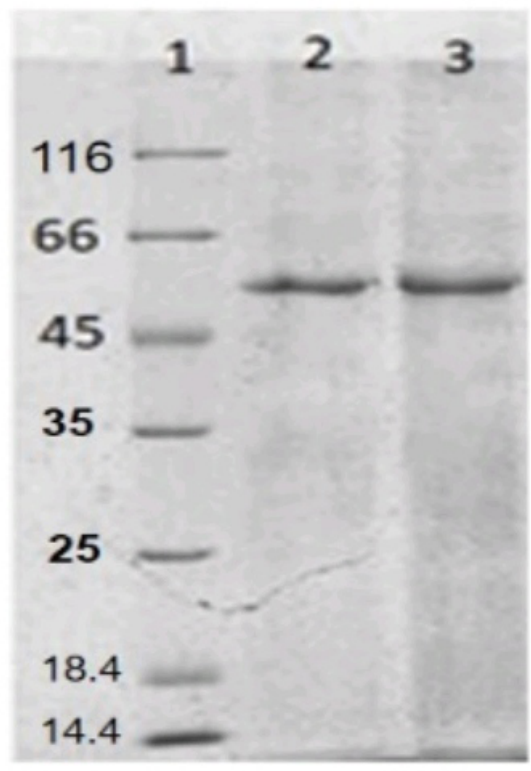

Figure 2. SDS PAGE analysis of purified antibodies

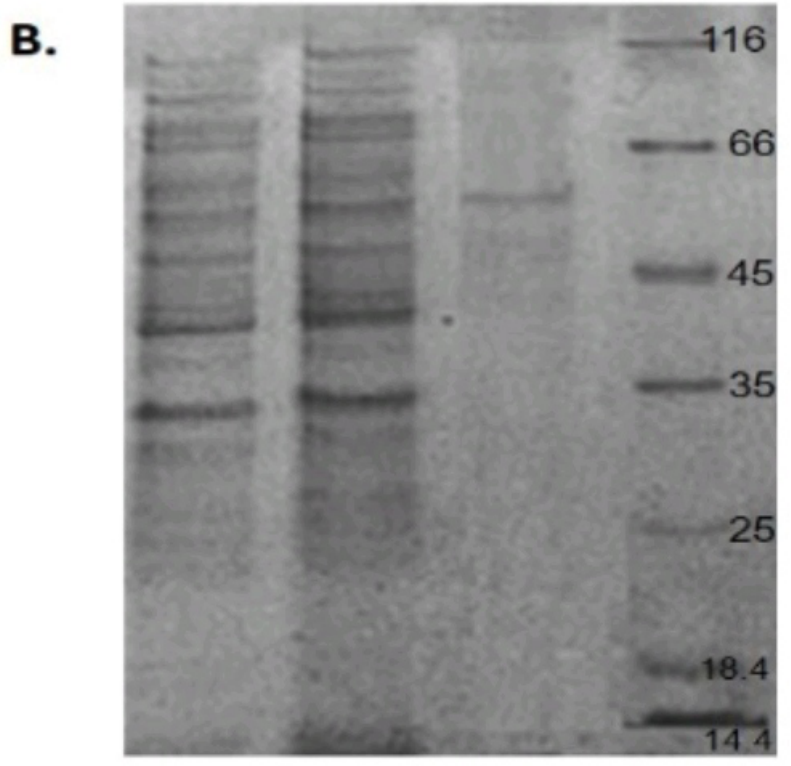

Quarterly of

The Horizon of Medical Sciences

A: Purified protein from the Expi293F cell expression system. Row 1) Marker protein 116-14 kDa Row 2 and 3) Purified fractions of cell soup; B: The purified protein of the BL21 (DE3) expression system. Row 1) Marker protein 116-14 kDa Row 2) Uninduced cell lysate. 3) IPTG-induced cell lysates 4) Purified fraction of IPTG-induced lysates. 


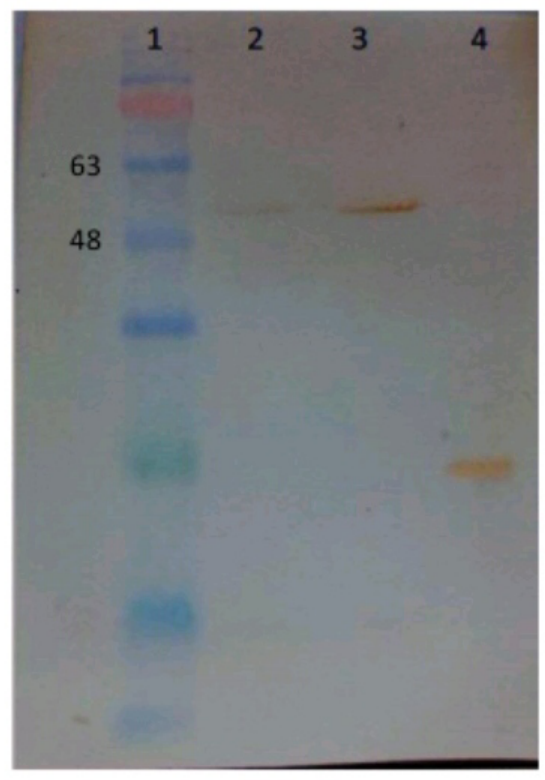

Figure 3. Western blot antibody test
B.

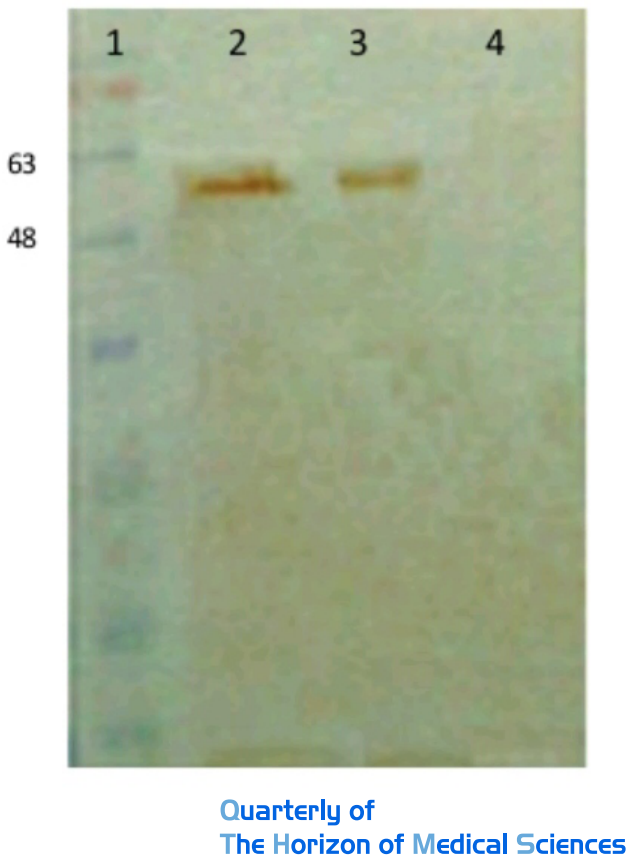

A: Western blotting performed on antibodies expressed in the Expi293F cell expression system. Row 1) Marker protein 10-180 kDa rows 2 and 3) Antibody of two purified traits. Row 4) Positive control protein with histidine sequence; B: Western blotting was performed on antibodies expressed in the BL21 (DE3) strain expression system. Row 1) Marker protein 10-180 kDa. Row 2) Cell lysates after induction with IPTG (containing dual-character antibodies) Row 3) Positive control protein with histidine sequence. Row 4) Uninduced cell lysate and no dual-character antibody (negative control). In both expression systems, coloring was performed by DAB.

cellulose membrane (GE Healthcare) to transfer proteins. After transfer, the membrane was blocked by $4 \%$ Bovine Serum Albumin (BSA). Next, the antibody against polyhistidine conjugated with HRP in a dilution of 1: 1500 was used. For the appearance of protein spots, 3 and 3 Deminobenzidine (DAB) methods were used.

\section{ELISA Assessment}

An ELISA test was used to evaluate the expression level of antibodies secreted by two different expression systems. For this purpose, CD19-expressing cell lines, called NALM-6, and CD3-expressing cell lines, called Jurkat were cultured in 96 cells overnight. The cells were then fixed using 3.7\% formaldehyde. After washing the cells 3 times, the unoccupied surfaces of the well were blocked by $2 \%$ bovine serum albumin for one hour. Next, the cells were incubated overnight with the serial dilutions of the antibody expressed at $4^{\circ} \mathrm{C}(12.5,6.25,3.12,1.56,0.58 \mathrm{pg} /$ $\mathrm{mL})$. After performing the re-washing steps, $100 \mu \mathrm{L}$ of antibody against HRP-conjugated polyhistidine was added to each well at a dilution of 1: 250 in 1\% BSA. After one hour and re-rinsing, $100 \mu \mathrm{L}$ of TMB (3,30,5,50 Tetramethylbenzidine) was added to each well to perform a dyeing reaction. Finally, the light absorption of each well was read with an ELISA reader at $450 \mathrm{~nm}$. Cell line without CD19 and $\mathrm{CD} 3$ markers (CHO cell) was also used as a negative control.

\section{Results}

The sequence encoding the blinatombe gene was successfully cloned into the pcDNA3.1 vector using two restriction enzymes NheI and HindIII. To confirm the cloning accuracy of the structure made by the two mentioned enzymes, an enzyme was digested which led to the creation of two pieces with a size of approximately 1600 and 5400 bp (Figure 1-A). In the case of the expression construct in bacteria, the coding sequence was successfully cloned into the pET-22b vector. Enzymatic digestion in this case also indicated the formation of 5000 and $1600 \mathrm{bp}$ formats (Figure 1-B). Finally, by sequencing the created structures, the cloning accuracy was confirmed in both cases.

The expression level in both expression systems was determined after purifying the protein with a nickel column (Figure 2). Moreover, the purified protein from each system was determined to be concentrated. This was $2.3 \mathrm{mg} / \mathrm{L}$ for Expi293F cells and $100 \mathrm{mg} / \mathrm{L}$ for the bacterial expression system. SDS PAGE analysis, followed by Western blotting 
was performed per expression system; this measure indicated the expression of $55 \mathrm{kDa}$ target protein at the respective site (Figure 3).

To evaluate the frequency of expression per case, a densitometric system was used to determine the density of each band in SDS PAGE gel. The obtained results revealed that the band related to the expression system in bacteria contained approximately $19.3 \%$ of the total proteins. Additionally, the band related to the mammalian cell expression system contains about $7.1 \%$ of the total cultured proteins (Table 1).
Antibody binding ability expressed by ELISA was assessed. Two NALM-6 cell lines were applied for CD19 and Jurkat cell line for CD3. Both classes were treated with serial dilutions of antibodies (Figure 4). The relevant results reflected that the extent of antibody binding expressed from the Expi293F cellular system was approximately twice as high as the antibody binding expressed in BL21 (DE3).

\section{Discussion}

The expression system of mammalian cells is of considerable significance in the biopharmaceutical industry. The special features of this system include high sensitivity; expensive culture media; the inherent complexity of

A

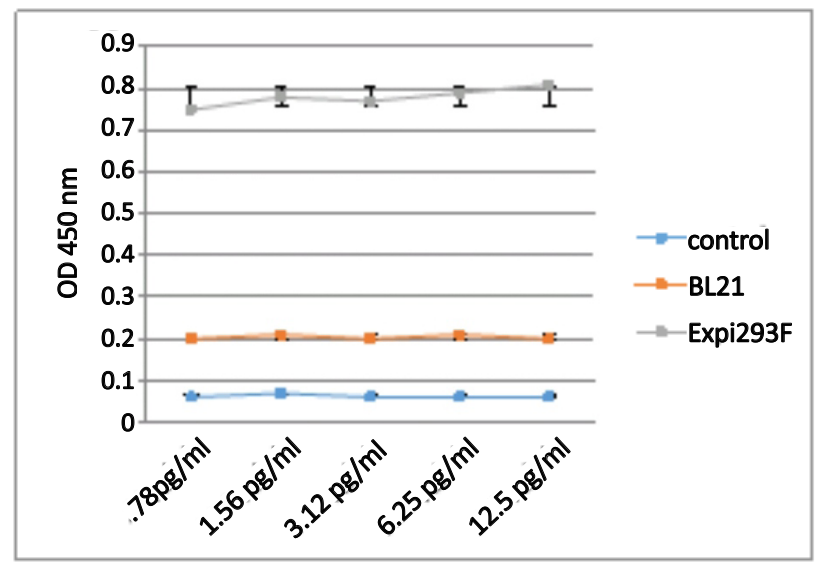

B

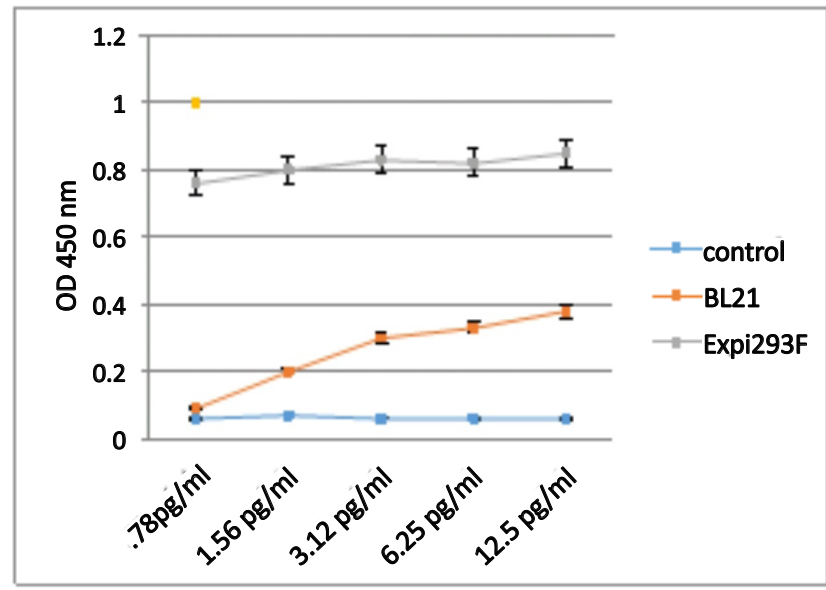

Quarterly of

The Horizon of Medical Sciences

Figure 4. Investigating the effect of antibody binding produced in Expi 293F expression system and BL-21 (DE3) strain to surface marker

A: of Jurkat cell; and B: NALM-6 cell in both types of antibody cells produced in the mammalian expression system further attaches to the target cell than the bacterial expression system. 
Table 1. SDS-PAGE gel densitometric analysis of the frequency of each band before and after purification with Ni-NTA column

\begin{tabular}{ccc}
\hline \multirow{2}{*}{ Expression system } & & $\%$ \\
\cline { 2 - 3 } & Before purification & After purification (\%) \\
\hline Expi 293F & 8.11 & 3.7 \\
BL21 (DE3) & 8.30 & 3.19 \\
\hline & & $\begin{array}{l}\text { Quarterly of } \\
\text { The Horizon of Medical Sciences }\end{array}$
\end{tabular}

eukaryotic cells, as well as the time-consuming process of culturing these cells. Such characteristics assist researchers in the field of industrial protein production research; they could use alternative systems in cases where simpler and cheaper hosts can be replaced. This also applies to producing antibody fragments or single-chain antibodies without a glycosylation pattern. A relevant challenge is to study the possibility of producing each molecule of a drug or antibody candidate protein in simpler expression systems, like bacteria. It is necessary to explore the possibility of production in cheaper systems for each protein separately; thus, the possibility of producing antibodies against the CD19 marker, as a powerful and expensive drug in the treatment of leukemia, was investigated (this antibody was available at the time of the release of the most expensive therapeutic antibody). This study compared and evaluated the produced protein using the method of rapid antibody production in the mammalian expression system (temporary expression system) and simultaneous expression in the bacterial system.

After successful cloning and expression of dual-character antibody in both systems, this antibody was purified and its production was confirmed. The expression levels in bacteria and Expi293F cells equaled $100 \mathrm{mg} / \mathrm{L}$ and $2.3 \mathrm{mg} / \mathrm{L}$, respectively. Mack et al. obtained the expression of $15 \mathrm{mg} / \mathrm{L}$ by the antibody expression of two anti-EpCAM $\times$ anti-CD3 properties in BiTE format in the bacterial host [22]. McCall et al. produced a dual-character antibody in a similar format against anti-HER2 / neu $\times$ anti-CD16 in bacteria with an expression level of about $3.7 \mathrm{mg} / \mathrm{L}$. Kuo et al. expressed the anti-CD123 $\times$ anti-CD3 antibody in the CHO-K1 host in a format similar to BiTE at a rate of about $5 \mathrm{mg} / \mathrm{L} \mathrm{[23].} \mathrm{The}$ level of expression in E.coli expression systems is generally higher than that in mammalian expression systems; however, Root et al. achieved a significant expression of 1300 $\mathrm{mg} / \mathrm{L}$ [24]. De Nardis et al. also produced dual-specific antibodies against HER2 and HER3 in the CHO-DG44 host in IgG-like formulation with an expression level of about $1200 \mathrm{mg} / \mathrm{L}[25]$.
The examined bacterial system reflected the ability to produce higher amounts of antibodies; however, the generated antibody had a lower binding power, compared to mammalian cells. Examining antibody binding characteristics produced per system by ELISA test signified that the mammalian expression system is more efficient in antibody production than the bacterial production system. In other words, the binding rate to each of the target indices (i.e., CD19 \& CD3) was averagely about twice as high. This is probably due to differences in folding systems and protein processing in mammalian cells and bacteria. Previous studies provided similar results [22]. Flow cytometric analysis can be used to more accurately evaluate the antibody binding power produced. Besides, a mixed lymphocyte culture system in the presence of target cells can be used to evaluate the cytotoxic effect of antibodies on the target cell [12, 26]. Additionally, further studies are suggested to evaluate the expression of this antibody in other common expression systems, such as other mammalian cells or yeast cells. Another approach is to implement different expression vectors in the mammalian expression system.

\section{Conclusion}

This study indicated that in the case of antibodies to two traits of the BiTE family, like Blinatombe, mammalian cells present a more efficient and successful expression system; although the bacterium can produce much larger amounts of the antibody.

Authors: Reza Moazami (laboratory and research methods, data analysis and text writing and editing) Hassan Mirza Hosseini (data analysis and text writing and editing) Fatemeh Nadafi (laboratory and research methods, text writing and editing) Fatemeh Davami (Research idea, conceptualization, data analysis, and text writing and editing) 


\section{Ethical Considerations}

\section{Compliance with ethical guidelines}

This research has obtained the ethics code IR.PII. REC.1399.008 from Pasteur Institute of Iran.

\section{Funding}

This research has been done using the research grant of Pasteur Institute of Iran and in this institute.

Authors' contributions

Laboratory and research methodology: Reza Moazami and Fatemeh Nadafi; Data analysis, writing - original draft, and writing - review \& editing: All Authors; Conceptualization: Fatemeh Davami.

\section{Conflicts of interest}

The authors declared no conflict of interest. 
This Page Intentionally Left Blank 
بيان مقايسهایى آنتى بادى دوخصيصهاى عليه ماركر CD19 بيمارى لوكمى لنفوبالاستيك حاد (ALL)

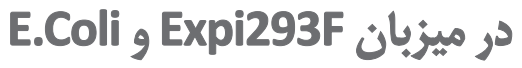

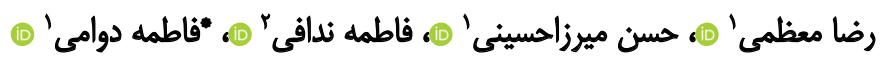
1. امركز تحقيقات بيوتكنولوزي يزشكى ايران، انستيتو ياستور ايران، تهران، ايران.

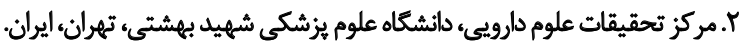

\section{حكיد}

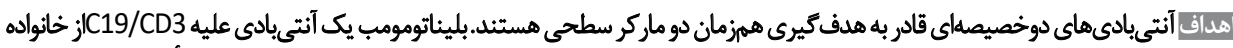

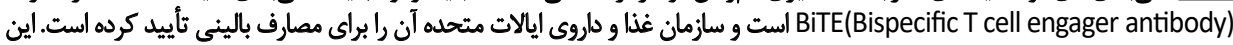

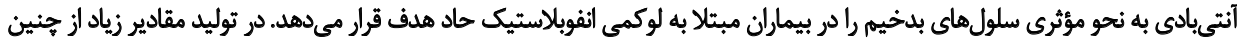

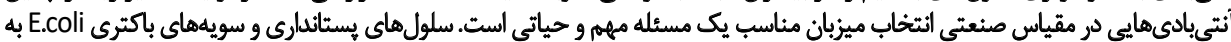

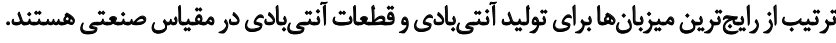

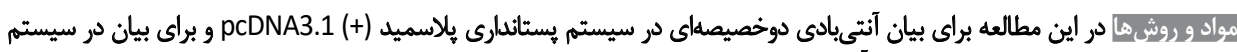

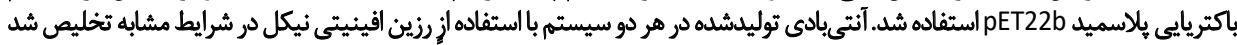

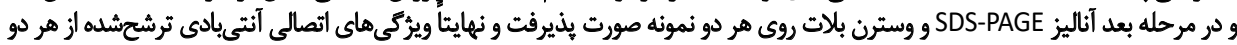

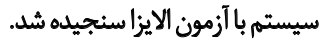

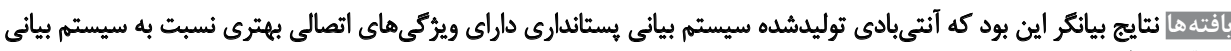
در باكثرى است.

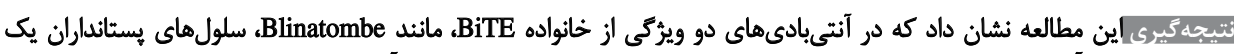

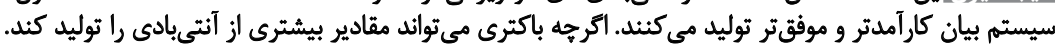

$$
\begin{aligned}
& \text { تاريخ دريافت: } 1 \mid \text { فروردين .. }
\end{aligned}
$$

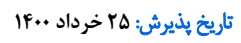

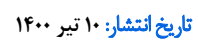

كليدواروها: بليناتومومب؛ آنتئيادى

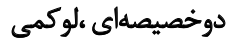
لنفوبلاستك حاد الوكيم

جنين محدوديتهايى و افزايش فعاليت ضدتومورى آنتىبادىها

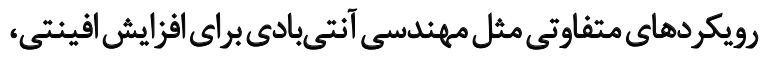

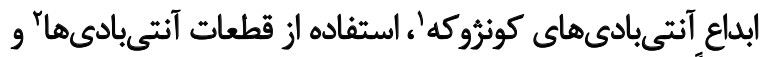

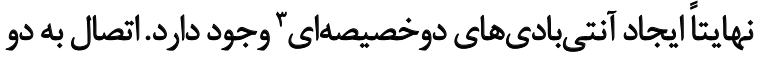

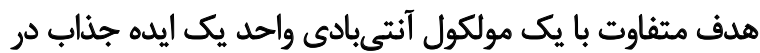

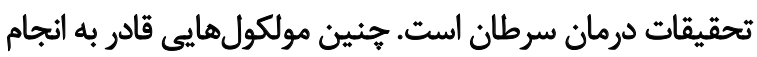

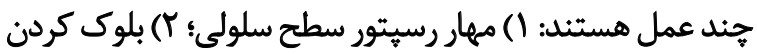

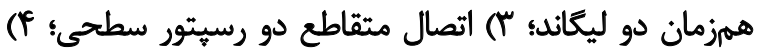

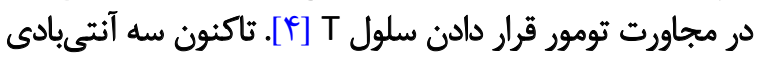

1. Antibody Drug Conjugate

2. Antibody fragments

3. Bispecific

-.

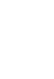

امروزه استفاده از آنتىبادىهاى منوكلونال (mAb) براى

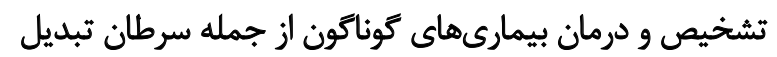

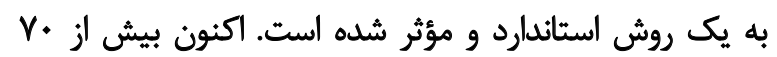

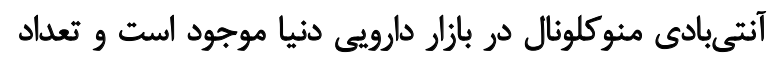

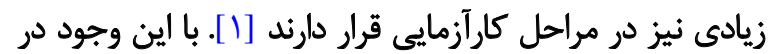

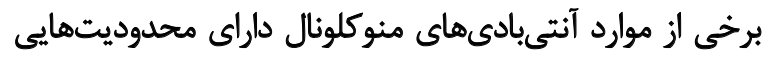

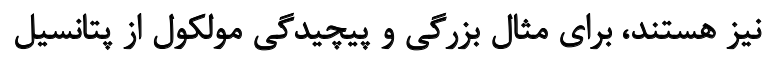

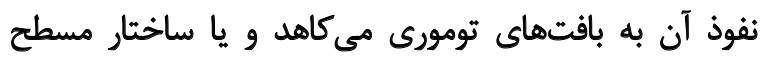

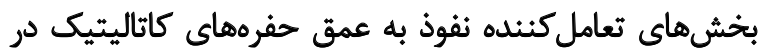

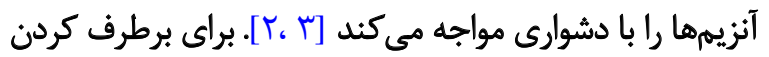

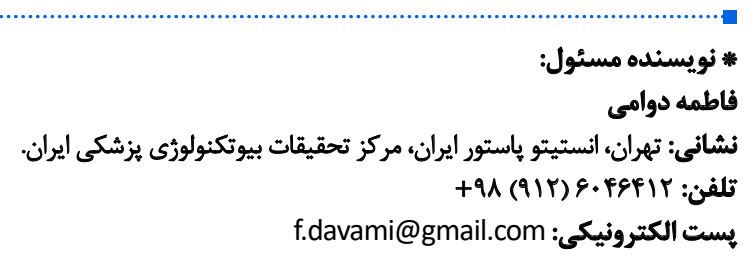


CD3×CD19 anti

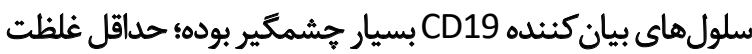
مورد نياز براى ليز سلول هدف واجد CD19 در حدود

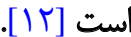

سل هاي CD4 ، CD3+ يا CD8+ توانايى مشابهى در ليز

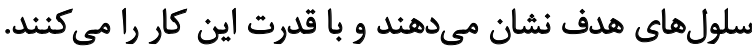

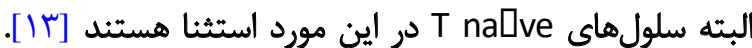

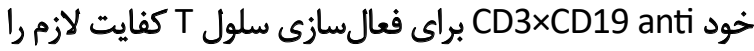

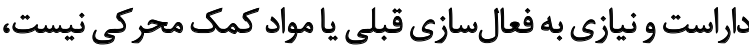

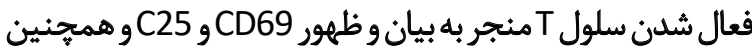
Up regulation آن شده واز طرف ديكر باعث رهايش سيتوكاينهاي التهابي مثل بـاني

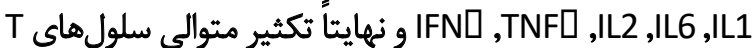

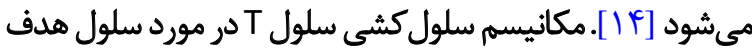
داراى CD19 شامل تشكيل يك سينايس سيتوليتيك محكم سئي

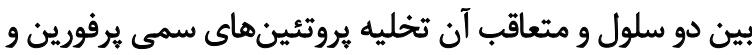

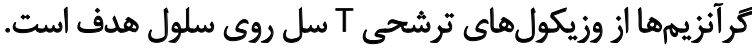

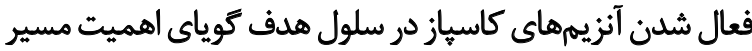

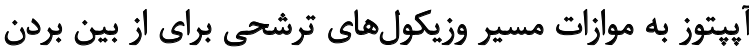

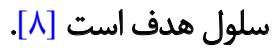

امروزه براى توليد بروتئينهاى نوتركيب درمانى از جمله

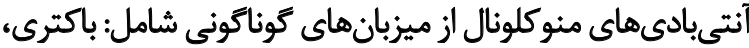

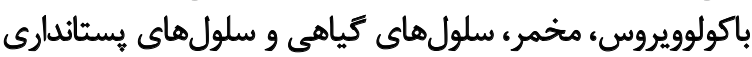

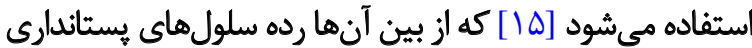

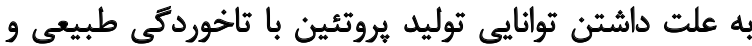

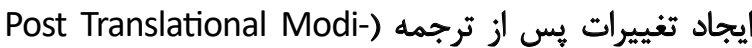

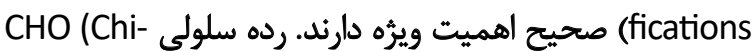

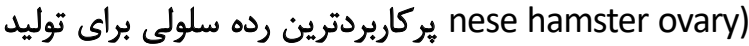

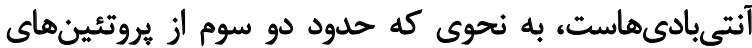

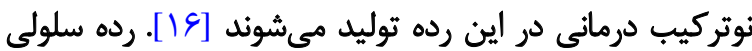
(HEK293 human embryonic kidney كليه انسان است و در حال حاضر به طور گستردالى براي بيان موقت كاليه انسان است وتروتئينهاي

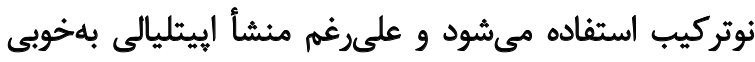

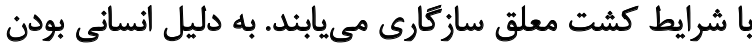

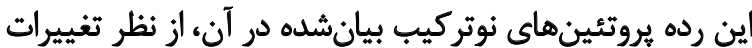

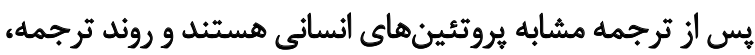

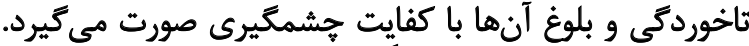

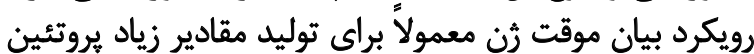

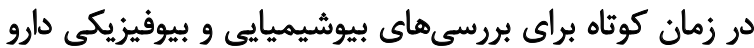

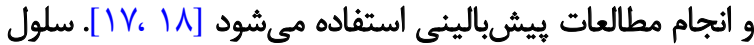
Expi 293

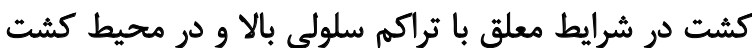

دوخصيصاى توانستهاند از مراجع قانونى مجوز ورود به بازار را

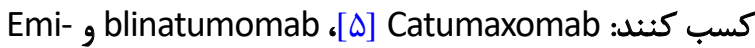
ائرجا cizumab

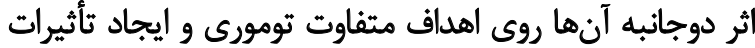

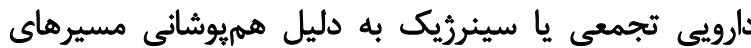

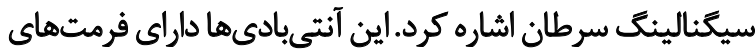

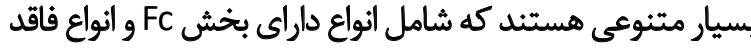

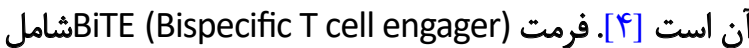

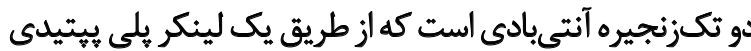

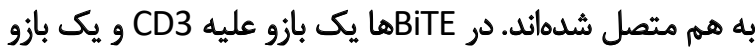

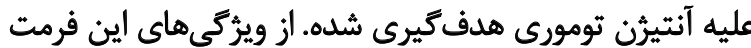

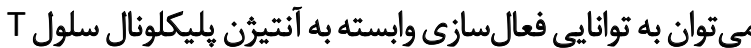

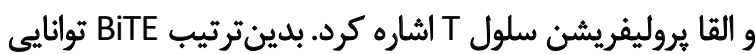

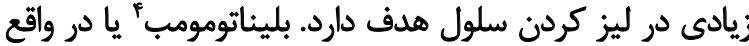
CD3×CD19bsAb anti ALL (Acute Lymphoblastic براي دران دركان Amgen شركان NHL (non-Hodgkin's lymphoma) و در سران ال

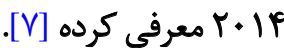

هليناتومومب فيورن يروتئينى با وزن مولكولى هD KD و

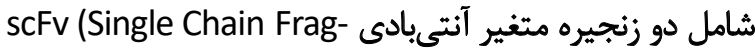
است. اين يروتئين از طريق ment Variable)

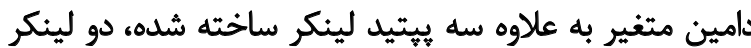

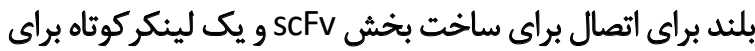

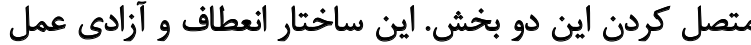

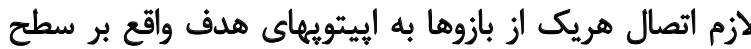

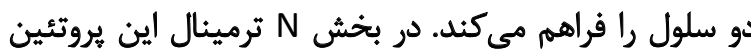

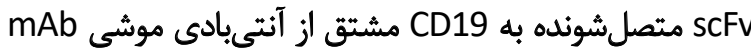

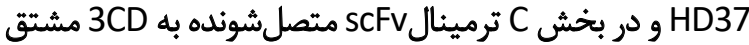

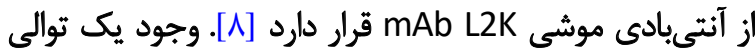

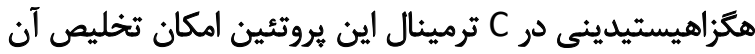

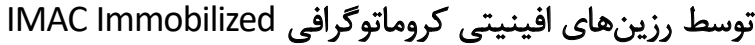
توا فراهم مي كند [9]

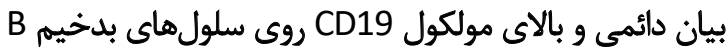

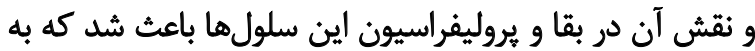

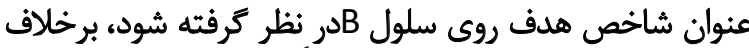

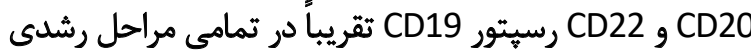

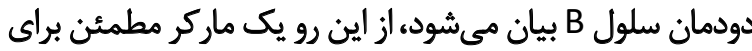

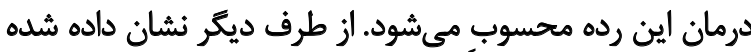

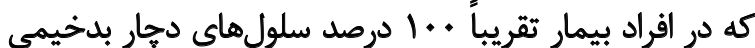

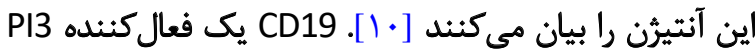

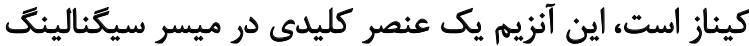

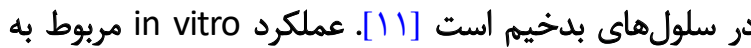

4. Blinatumomab 


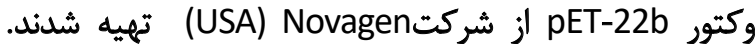

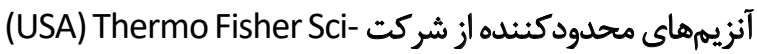
خريدارى شدند. رده سلولى Jurkat و لentific سلولى انستيتو ياستور ايران تهيه شدند.

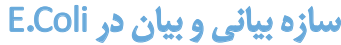

سازه بيانى بيانكننده آنتىبادى دوخصيصهاي بليناتومومب

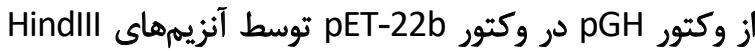

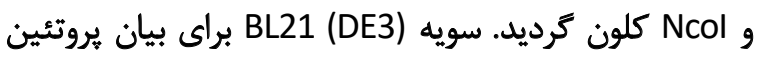

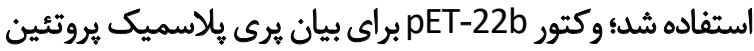

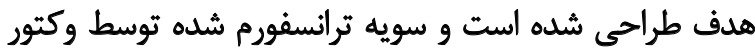

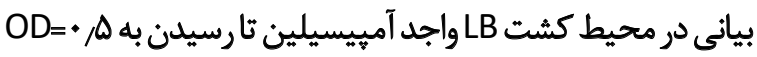

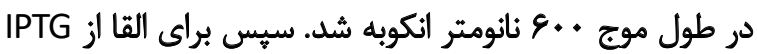

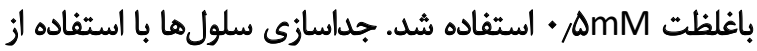

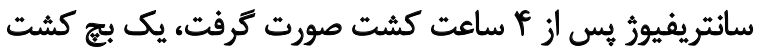

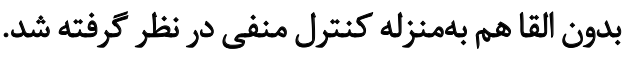

\section{سازوه بياني و ويان وده سلولي Expi293F}

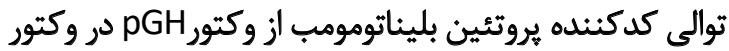

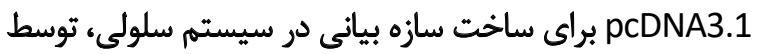

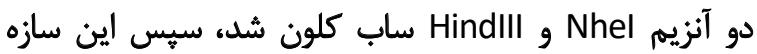

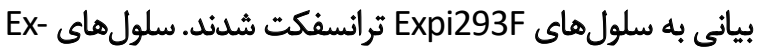

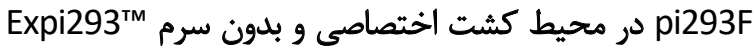

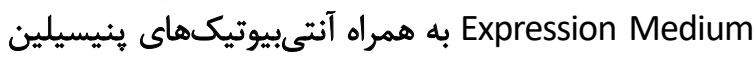
استريتومايسين (2mM كشت شدند. سلولهاد شيط شيكر انكوباتور

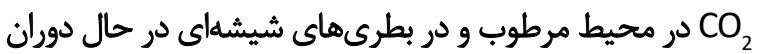

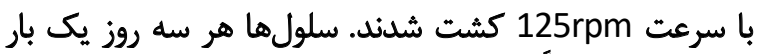

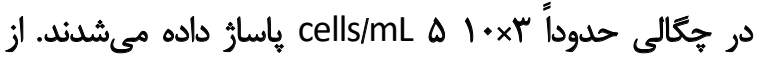

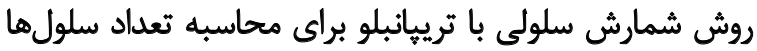

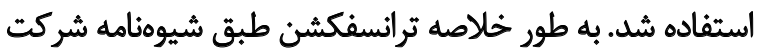

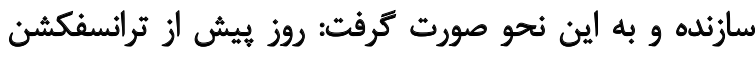

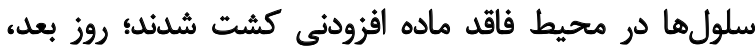
ماده ترانسفكت كنينده (ExpiFectamine

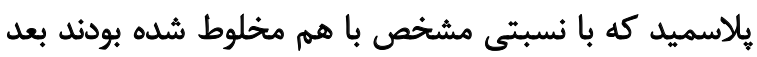

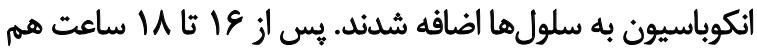
ExpiFectamine ${ }^{\mathrm{TM}}$ Transfection Enhancer 1\&2 دستورالعمل سازنده به سلول ها افزوده شدئد. در روز هفتم محيط براي رويى از سلولها جدا شده و براي ارزيابى ميزان بيان ذخيره كرديد.

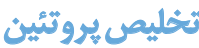

براي تخليص آنتىبادى بيانشده توسط رده سلولى Expi293F (الى شداد ) از ستون Ni-NTA (Ni-Nitrilotriacetic acid) استفاده شدان
عارى از سرم و به شكل Chemically Defined تطابق يافته

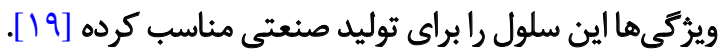

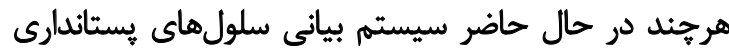

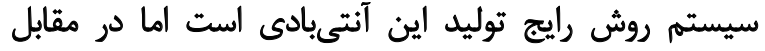

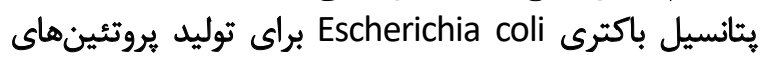

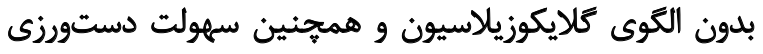

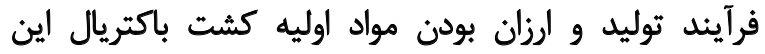

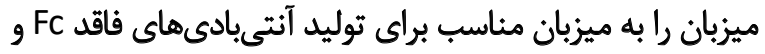

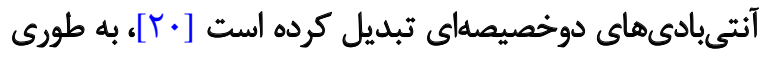

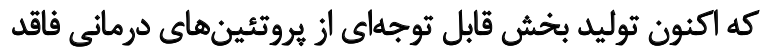

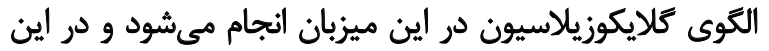

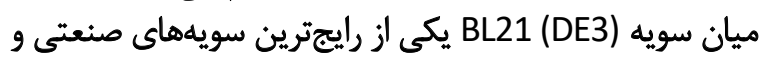

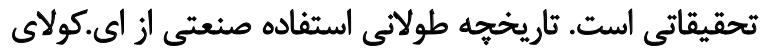

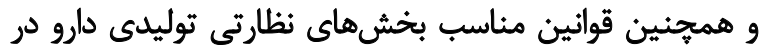

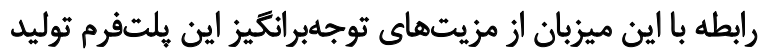

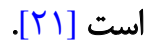

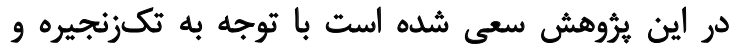

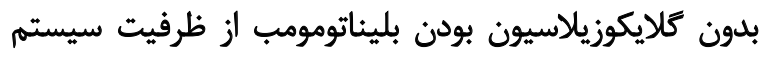

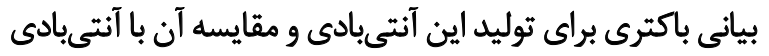

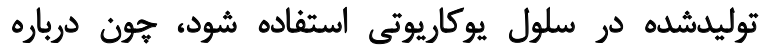

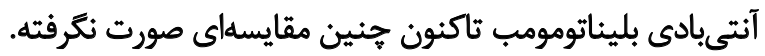

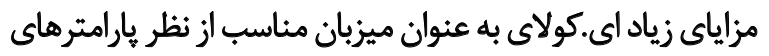

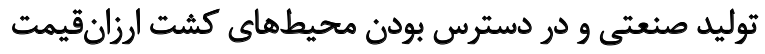
براى توليد زيست داروها در اين ميزبان و همجنين

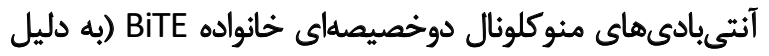

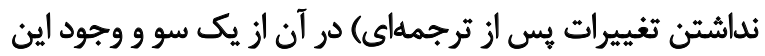

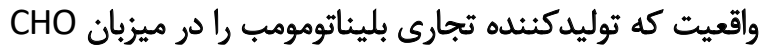

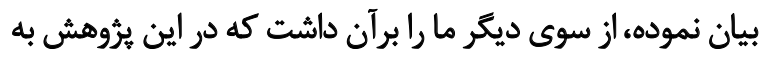

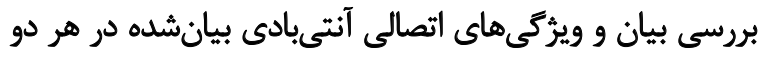
سيستم و مقايسه آنها بيردازيهم.

مواد و روشها - ماش

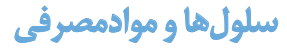

سلول Expi293F و ماده ترانسفكشن (Expi293' مخصوص به آن

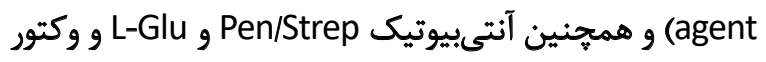

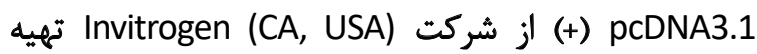

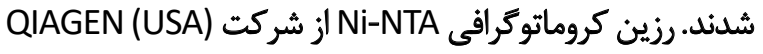

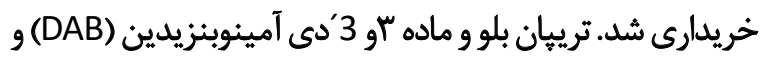

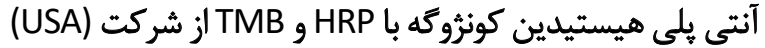

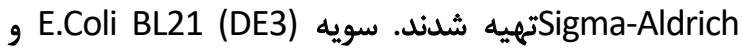




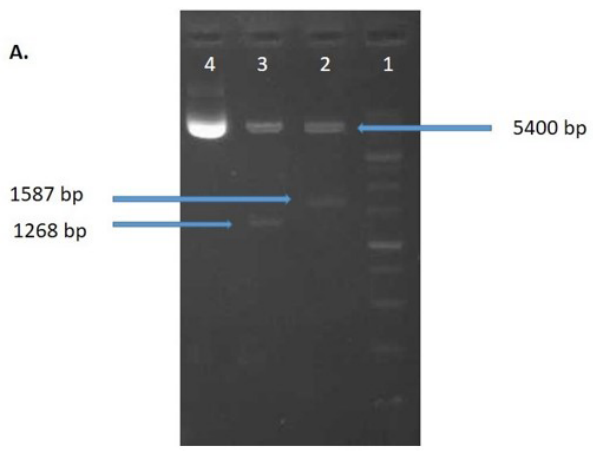

B.

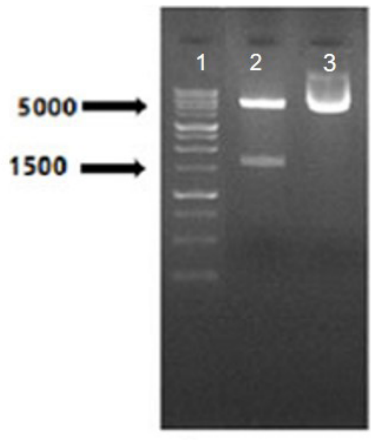

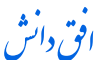

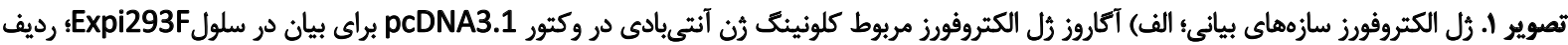

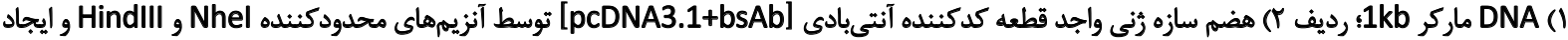

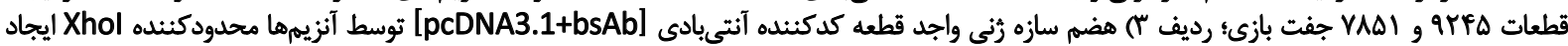

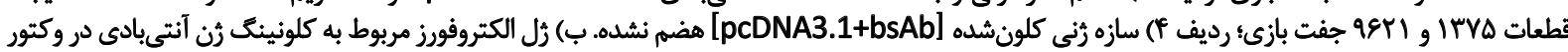

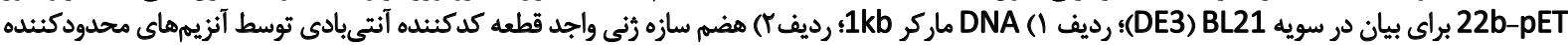
HindIII , Ncol

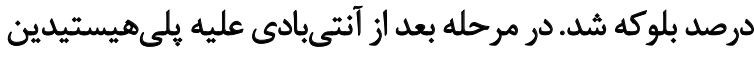

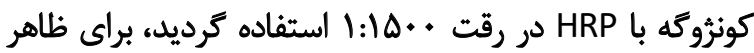

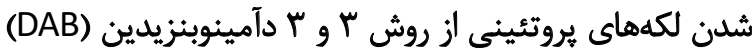
|ستفاده شد.

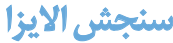

براى بررسى سطح بيان آنتىبادى ترشحشده توسط دو

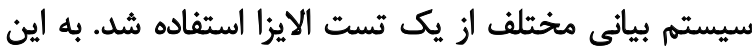

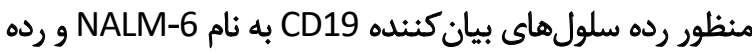

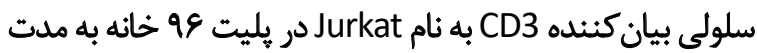

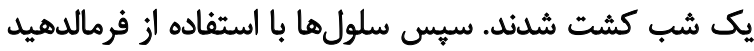

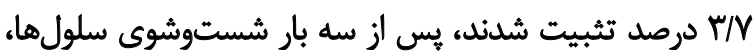

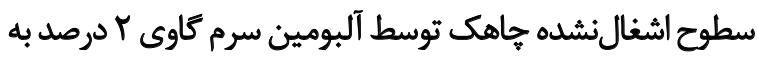

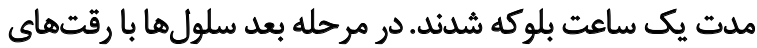

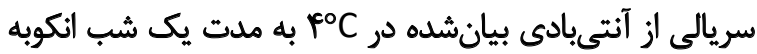

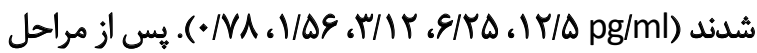

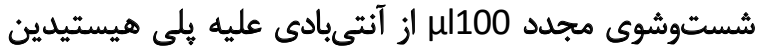

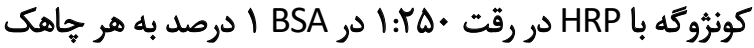

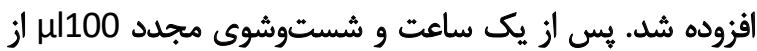

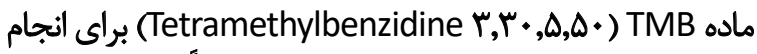

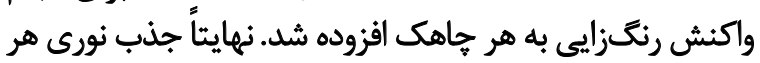

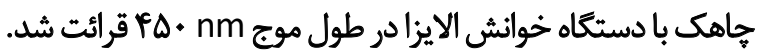

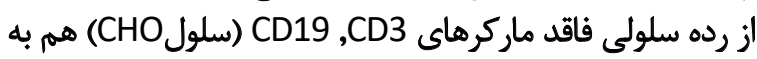

$$
\text { عنوان كنترل منفى استفاده شد. }
$$

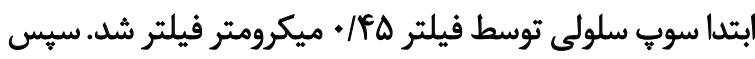

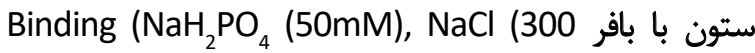
شستوشو داده شد؛ در مرحله بعد نمونه باسرعت 1ml/min روى ستون اعمال گرديد

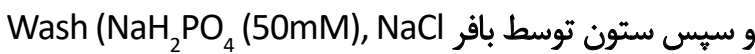
شستوشو (300 mM), imidazole (20 mM), pH =8.0) NaH $\mathrm{PO}_{4}(50 \mathrm{mM}), \mathrm{NaCl}$ (300 mM), داده شد و نهايتاً بافر imidazole (250 mM) pH =8.0)Elution

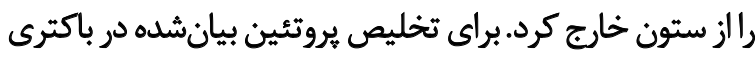

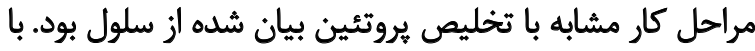

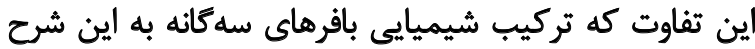

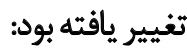

Binding buffer: (100mM NaH ${ }_{2} \mathrm{PO}_{4^{\prime}}, 10 \mathrm{mM}$ Tris, 8 $\mathrm{M}$ Urea $\mathrm{pH}=8$ )

Washing buffer: (100mM NaH $\mathrm{PO}_{4}, 10 \mathrm{mM}$ Tris, 8 $\mathrm{M}$ Urea $\mathrm{pH}=6.3$ )

Elution buffer: $\left(100 \mathrm{mM} \mathrm{NaH}_{2} \mathrm{PO}_{4}, 10 \mathrm{mM}\right.$ Tris, 8 $\mathrm{M}$ Urea $\mathrm{pH}=4.5$ )

\section{أثاليز}

از آناليز SDS PAGE و وسترن بلات براي ارزيابى ميزان بيان

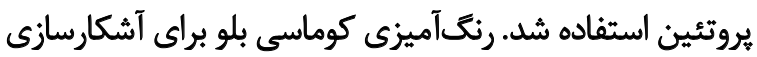

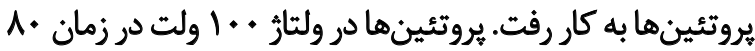

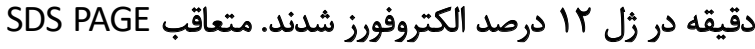
وسترن بلاتينگ صورت بذيرفت. اين فرايند توسط دستخاه

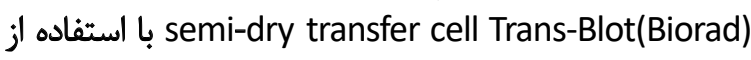
غشاى نيترو سلولز (GE Healthcare) براى انتقال بروتئينها

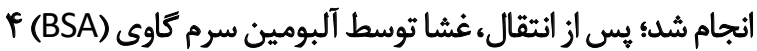


A.

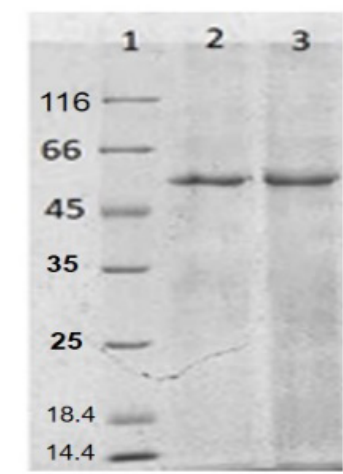

B.

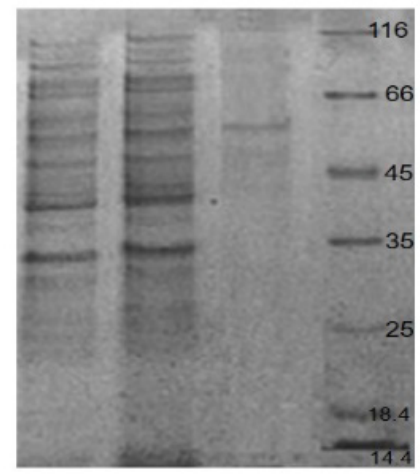

انق

تصوير r. آناليز

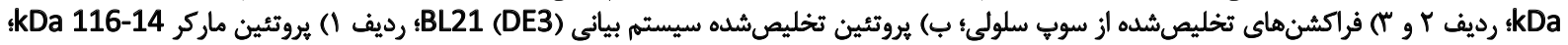

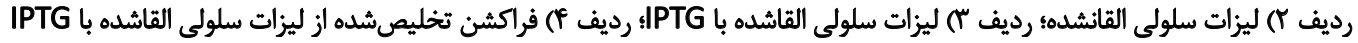

\section{أناليز بيان بوروتينين}

Ladị̂?

ميزان بيان در هر دو سيستم بيانى متعاقب انجام تخليص بروتئين باستون نيكل صورت كرفت (تصوير شماره بان ) و يروتيئن

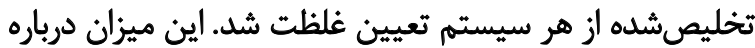

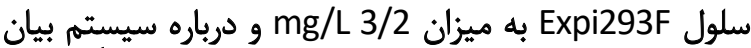

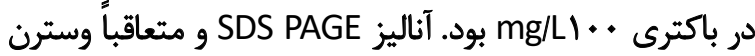

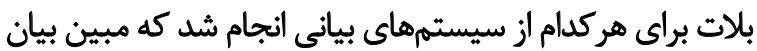

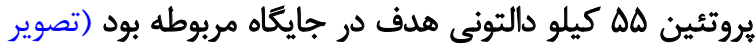

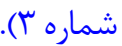

براي بررسي درصد بيان در هرمورد، از سيستم دانسيتومترى

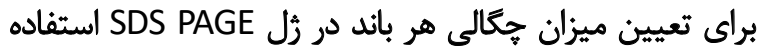

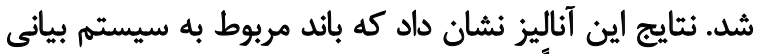

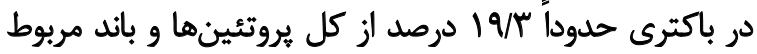

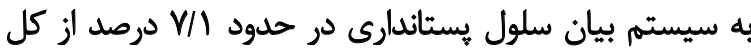

\section{توليد سازههاي ياني}

pCD- توالى كدكنيده رثن بليناتومومب با موفقيت در وكتور

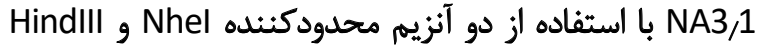

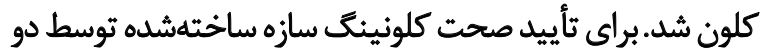

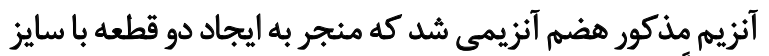

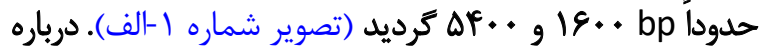
سازه بياني در باكترى هم توالي كدكنيده با موفقيت در وكتور

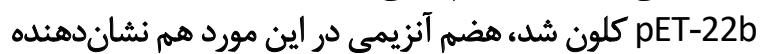

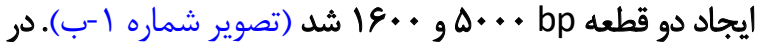

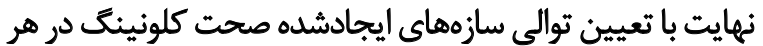
دو مورد تأييد شد.
A.

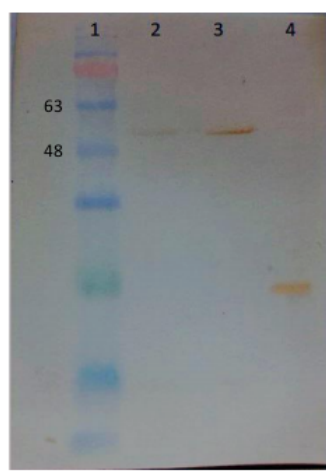

B.

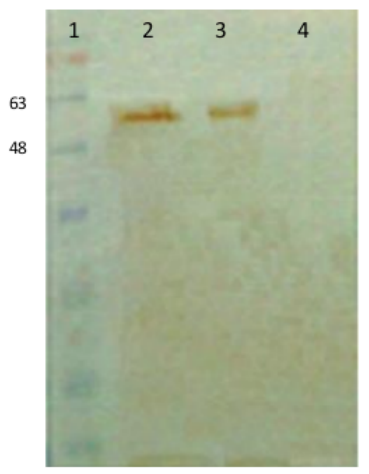

نو

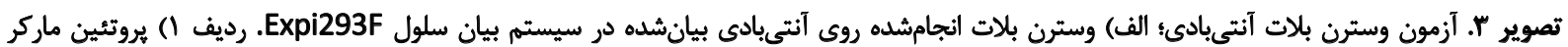
180 kDa

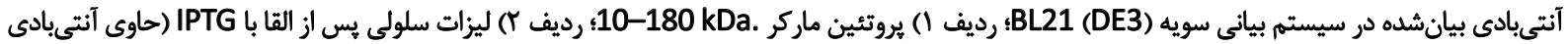

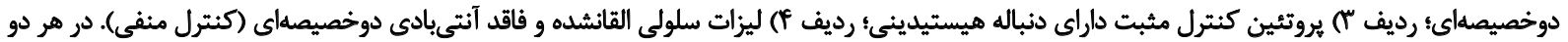
سيستم بيانى رنكآميزى توسط DAB صورت كرئ مرفته است. 
A

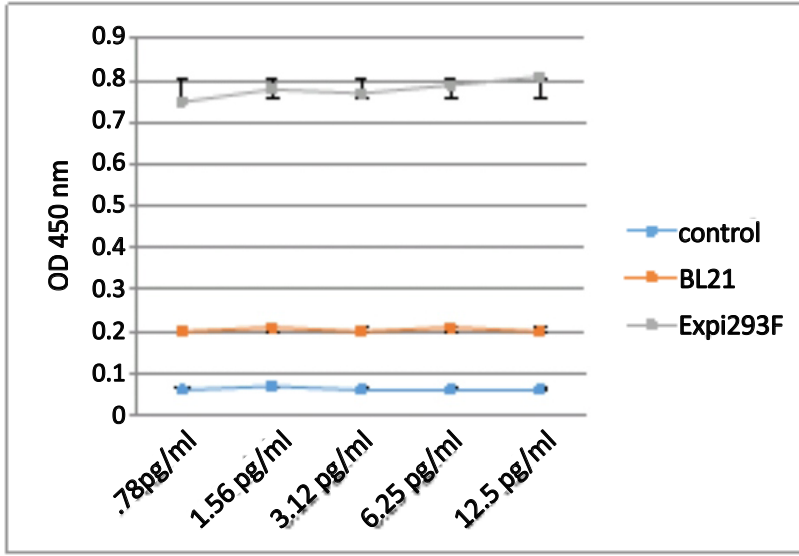

B

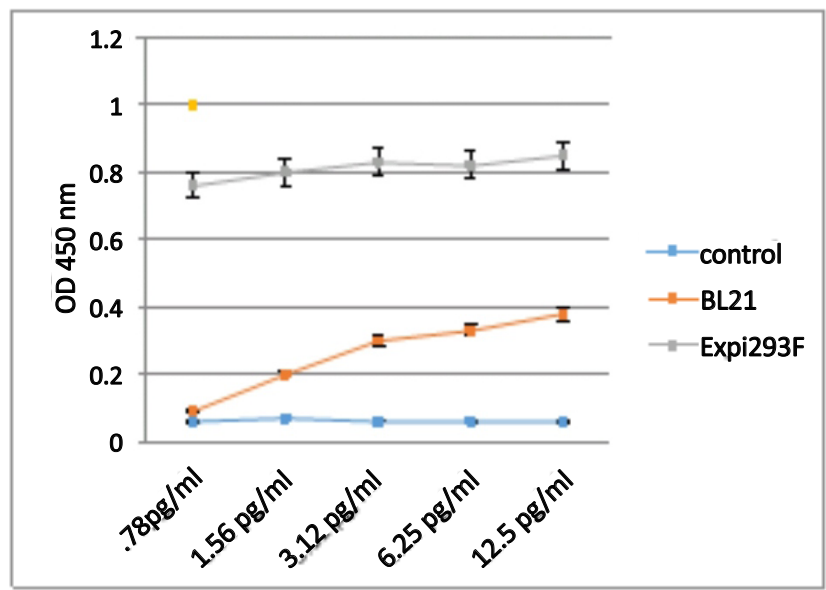

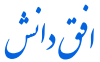

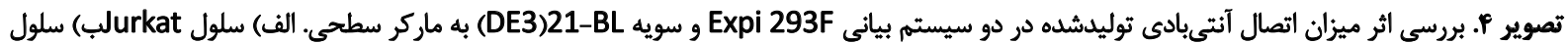

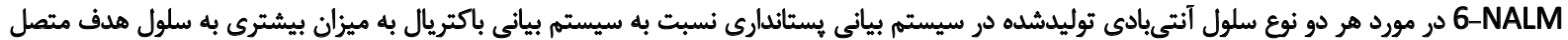
مي شود.

سلولي Jurkat براي CD3 استثاده شد. هر دو رده با رقتهاي بروتئينهاى كشت راشامل ميشود (جدول شماره ().

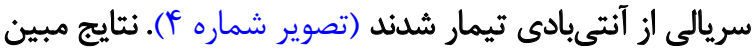

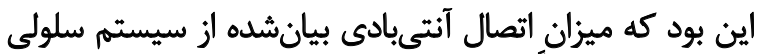

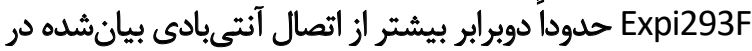

\section{بروسي توانايي اتمال أنتثيادى به سلول هدف} سويه (DL21 (DE3) است.

بررسي ثوانايي اتصالى آنتىبادى بيانشده با استفاده از آزمون

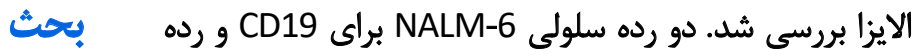

جدول ا. آناليز دانسيتومترى رُل EGAP -SDS درصد هر باند ازٔ قبل و بعد از تخليص با ستون ATN-iN

\begin{tabular}{|c|c|c|}
\hline سيستهم بيانى & قبل از تخليص & بعد از تضخليص \\
\hline Expi 293F & $11 / 1 \%$ & v/r\% \\
\hline BL21(DE3) & $\mu \cdot 11 \pi \%$ & $19 / r \%$ \\
\hline
\end{tabular}

إنُانُ 
آزمون الايزا، نشان داد كه سيستم بيان هيستاندارى در توليد

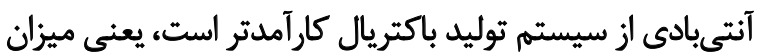

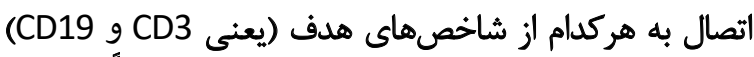

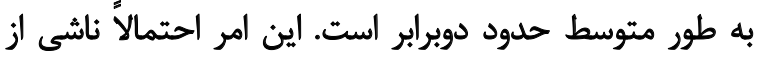

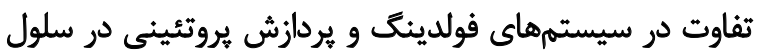

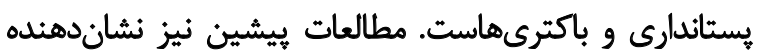

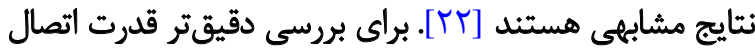

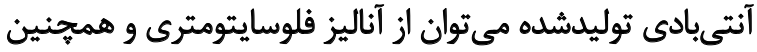

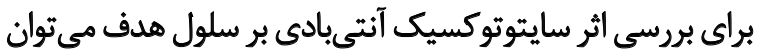

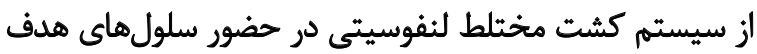

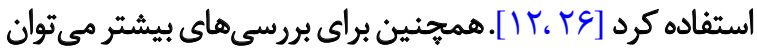

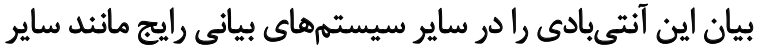

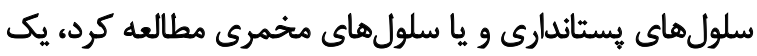
رويكرد ديكر نيز استفاده از وكتورهاي بيانى متفاوت ديان در سيستم بيان يستاندارى است.

\section{نتيجليَّيرى}

انجام اين بروهش نشان داد كه درباره آنتىبادىهاى

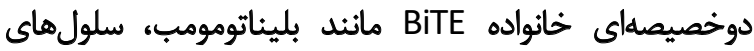

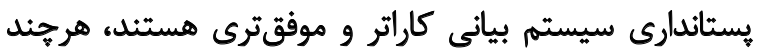

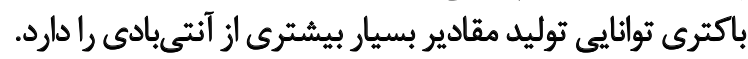

مالاحظاث اخلاقي

\section{يبيووى أو الصول الخالاق يُووهش}

اين يروهش داراى كد اخلاق IR.PII.REC.1399.008 از

انستيتو ياستور ايران است.

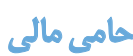

اين يُروهش با استفاده از گرنت تحقيقاتى انستيتوياستور ايران

و در اين مؤسسه انجام شده است.

مشاركت نويسند مكان

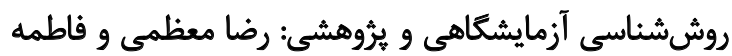

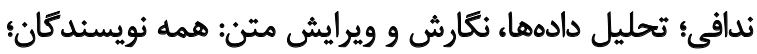
ايده يُوهشى و مفهومسازى: فاطمه دوامى. نئ.

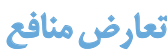

نويسندكان هيج كونه تعارض منافعى اعلام نكردند.
هر جند كه امروزه سيستم بيانى سلول هاى يستانداري در صنعت

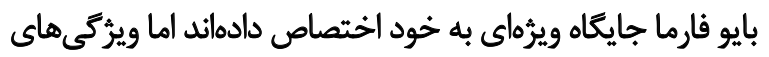

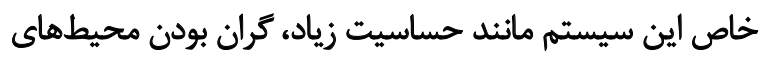

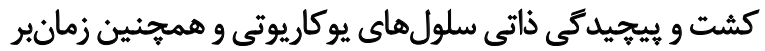

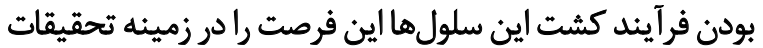

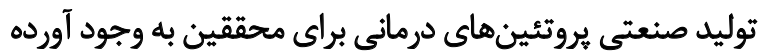

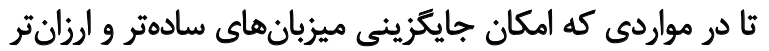

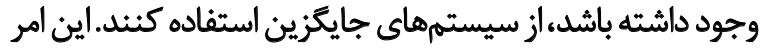

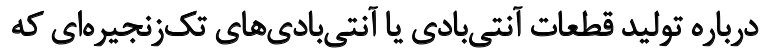

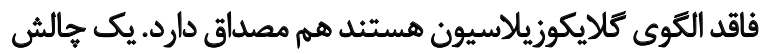

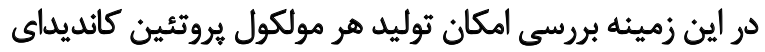

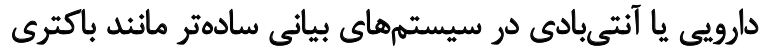

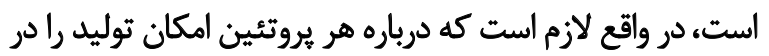

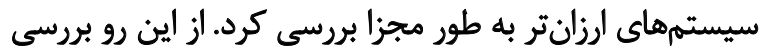

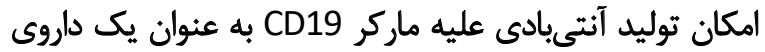

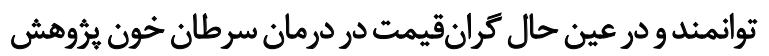

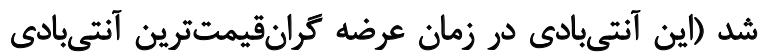

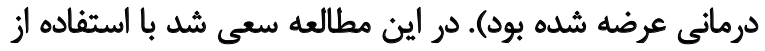

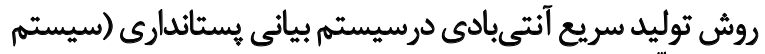

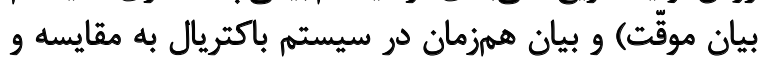
بررسى يروتئين توليدشده برداخته شود.

يس از كلونينگ و بيان موفق آنتىبادى دوخصيصهاى در هر إني

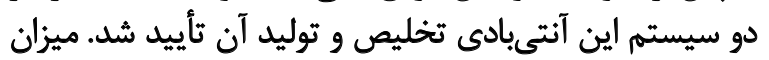

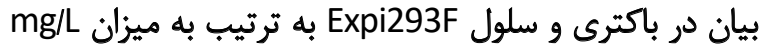

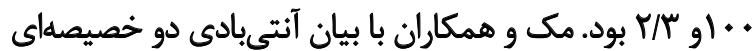
anti-EpCAM × anti-CDr

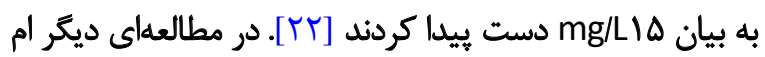

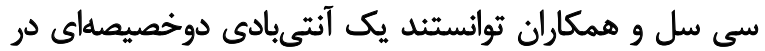

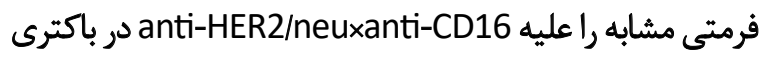

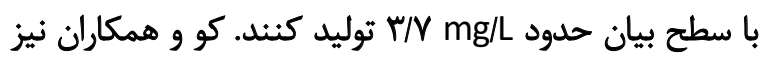

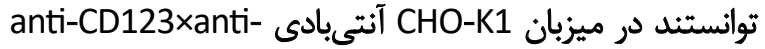

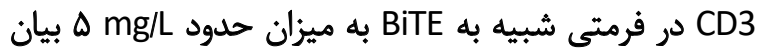

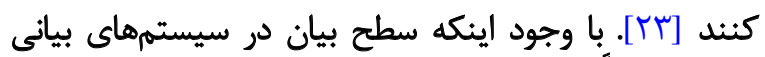
E.Coli

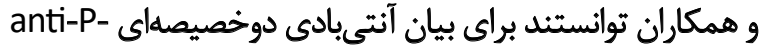

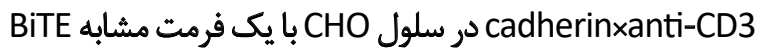

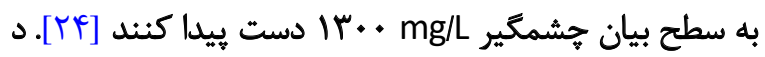

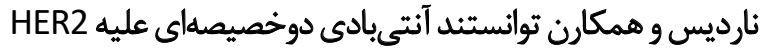

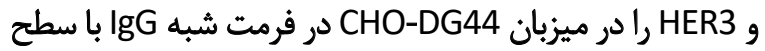

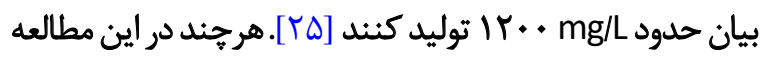
سيستم باكترى توانايى توليد مقادير بيشترى ازئ آنتى بادى رانيد رانشان

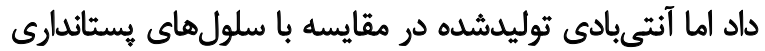

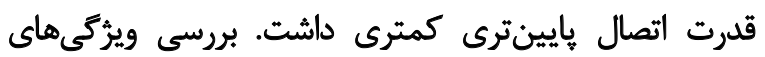

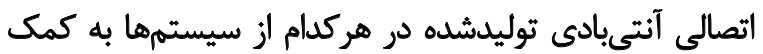




\section{References}

[1] Wurm FM. Production of recombinant protein therapeutics in cultivated mammalian cells. Nature Biotechnology. 2004; 22(11):1393-8. [DOI:10.1038/nbt1026] [PMID]

[2] Weidle UH, Auer J, Brinkmann U, Georges G, Tiefenthaler G. The emerging role of new protein scaffold-based agents for treatment of cancer. Cancer Genomics-Proteomics. 2013; 10(4):155-68. [PMID]

[3] Cruz E, Kayser V. Monoclonal antibody therapy of solid tumors: Clinical limitations and novel strategies to enhance treatment efficacy. Biologics: Targets \& Therapy. 2019; 13:33-51. [DOI:10.2147/BTT.S166310] [PMID]

[4] May C, Sapra P, Gerber HP. Advances in bispecific biotherapeutics for the treatment of cancer. Biochemical Pharmacology. 2012; 84(9):110512. [DOI:10.1016/j.bcp.2012.07.011] [PMID]

[5] Thakur A, Lum LG. "NextGen" biologics: Bispecific antibodies and emerging clinical results. Expert Opinion on Biological Therapy. 2016; 16(5):675-88. [DOI:10.1517/14712598.2016.1150996] [PMID]

[6] Husain B, Ellerman D. Expanding the boundaries of biotherapeutics with bispecific antibodies. BioDrugs. 2018; 32(5):441-64. [DOI:10.1007/ s40259-018-0299-9] [PMID]

[7] Baeuerle PA, Reinhardt C. Bispecific T-cell engaging antibodies for cancer therapy. Cancer Research. 2009; 69(12):4941-4. [DOI:10.1158/00085472.CAN-09-0547] [PMID]

[8] Nagorsen D, Baeuerle PA. Immunomodulatory therapy of cancer with T cell-engaging BiTE antibody blinatumomab. Experimental Cell Research. 2011; 317(9):1255-60. [DOI:10.1016/j.yexcr.2011.03.010] [PMID]

[9] Löffler A, Kufer P, Lutterbüse R, Zettl F, Daniel PT, Schwenkenbecher $\mathrm{JM}$, et al. A recombinant bispecific single-chain antibody, CD19 $\times$ CD3, induces rapid and high lymphoma-directed cytotoxicity by unstimulated T lymphocytes. Blood. 2000; 95(6):2098-103. [DOI:10.1182/blood. V95.6.2098] [PMID]

[10] Portell CA, Wenzell CM, Advani AS. Clinical and pharmacologic aspects of blinatumomab in the treatment of B-cell acute lymphoblastic leukemia. Clinical Pharmacology: Advances and Applications. 2013; 5(Suppl 1):5-11. [DOI:10.2147/CPAA.S42689] [PMID]

[11] Baracho GV, Miletic AV, Omori SA, Cato MH, Rickert RC. Emergence of the PI3-kinase pathway as a central modulator of normal and aberrant $B$ cell differentiation. Current Opinion in Immunology. 2011; 23(2):178-83. [DOI:10.1016/j.coi.2011.01.001] [PMID]

[12] Dreier T, Lorenczewski G, Brandl C, Hoffmann P, Syring U, Hanakam $\mathrm{F}$, et al. Extremely potent, rapid and costimulation-independent cytotoxic T-cell response against lymphoma cells catalyzed by a single-chain bispecific antibody. International Journal of Cancer. 2002; 100(6):690-7. [DOI:10.1002/ijc.10557] [PMID]

[13] Kischel P, Guillonneau F, Dumont B, Bellahcène A, Stresing V, Clézardin $P$, et al. Cell membrane proteomic analysis identifies proteins differentially expressed in osteotropic human breast cancer cells. Neoplasia. 2008; 10(9):1014-20. [DOI:10.1593/neo.08570] [PMID]

[14] Brandl C, Haas C, d'Argouges S, Fisch T, Kufer P, Brischwein K, et al. The effect of dexamethasone on polyclonal $T$ cell activation and redirected target cell lysis as induced by a CD19/CD3-bispecific singlechain antibody construct. Cancer Immunology, Immunotherapy. 2007; 56(10):1551-63. [DOI:10.1007/s00262-007-0298-z] [PMID]

[15] Celik E, Calık P. Production of recombinant proteins by yeast cells. Biotechnology Advances. 2012; 30(5):1108-18. [DOI:10.1016/j.biotechadv.2011.09.011] [PMID]
[16] McAtee AG, Templeton N, Young JD. Role of Chinese hamster ovary central carbon metabolism in controlling the quality of secreted biotherapeutic proteins. Pharmaceutical Bioprocessing. 2014; 2(1):63-74. https://www.vanderbilt.edu/younglab/pdf/mcatee14.pdf

[17] Baldi L, Hacker DL, Adam M, Wurm FM. Recombinant protein production by large-scale transient gene expression in mammalian cells: State of the art and future perspectives. Biotechnology Letters. 2007; 29(5):677-84. [DOI:10.1007/s10529-006-9297-y] [PMID]

[18] Wurm F, Bernard A. Large-scale transient expression in mammalian cells for recombinant protein production. Current Opinion in Biotechnology. 1999; 10(2):156-9. [DOI:10.1016/S0958-1669(99)80027-5] [PMID]

[19] Wang Q, Chen Y, Park J, Liu X, Hu Y, Wang T, et al. Design and production of bispecific antibodies. Antibodies. 2019; 8(3):43. [DOI:10.3390/ antib8030043] [PMID]

[20] Demain AL, Vaishnav P. Production of recombinant proteins by microbes and higher organisms. Biotechnology Advances. 2009; 27(3):297306. [DOI:10.1016/j.biotechadv.2009.01.008] [PMID]

[21] Humphreys DP. Production of antibodies and antibody fragments in Escherichia coli and a comparison of their functions, uses and modification. Current Opinion in Drug discovery \& Development. 2003; 6(2):18896. [PMID]

[22] Mack M, Riethmüller G, Kufer P. A small bispecific antibody construct expressed as a functional single-chain molecule with high tumor cell cytotoxicity. Proceedings of the National Academy of Sciences of the United States of America. 1995; 92(15):7021-5. [DOI:10.1073/ pnas.92.15.7021] [PMID]

[23] Kuo SR, Wong L, Liu JS. Engineering a CD123xCD3 bispecific SCFv immunofusion for the treatment of leukemia and elimination of leukemia stem cells. Protein Engineering, Design \& Selection. 2012; 25(10):561-9. [DOI:10.1093/protein/gzs040] [PMID]

[24] Root AR, Cao W, Li B, LaPan P, Meade C, Sanford J, et al. Development of PF-06671008, a highly potent anti-P-cadherin/anti-CD3 bispecific DART molecule with extended half-life for the treatment of cancer. Antibodies. 2016; 5(1):6. [DOI:10.3390/antib5010006] [PMID]

[25] De Nardis C, Hendriks LA, Poirier E, Arvinte T, Gros P, Bakker ABH, et al. A new approach for generating bispecific antibodies based on a common light chain format and the stable architecture of human immunoglobulin G1. Journal of Biological Chemistry. 2017; 292(35):14706-17. [DOI:10.1074/jbc.M117.793497] [PMID]

[26] Hoffmann P, Hofmeister R, Brischwein K, Brandl C, Crommer S, Bargou $R$, et al. Serial killing of tumor cells by cytotoxic $T$ cells redirected with a CD19-/CD3-bispecific single-chain antibody construct. International Journal of Cancer. 2005; 115(1):98-104. [DOI:10.1002/ijc.20908] [PMID] 
This Page Intentionally Left Blank 